\title{
The birds of Glasgow Botanic Gardens
}

\author{
C.J. McInerny \\ School of Life Sciences, University of Glasgow, Glasgow G12 8QQ \\ E-mail: chris.mcinerny@glasgow.ac.uk
}

\begin{abstract}
A summary is presented of the bird species recorded in Glasgow Botanic Gardens, Scotland for the period 1998-2020. Comparisons are made against similar bird lists made over the past 100 years, with trends and changes described and discussed. A few observations of unusual and rarely seen species are included.
\end{abstract}

\section{INTRODUCTION}

This paper is one of a series describing the wildlife of Glasgow Botanic Gardens (GBG), and how it has changed over the years (Downie \& Forster, 2019). The Gardens contain a number of habitats supporting different types of birds, in an otherwise largely urbanised area of a major city. This has resulted in a wide range of species being recorded over the years and these have been tabulated into bird lists. Such lists have been compiled by various authors, summarised by Grist \& McCallum (1998), who completed their own bird list for the years 1994-1997. Other data about the birds observed in GBG were provided by Richard Weddle through the Glasgow Museums Biological Record Centre:

http://www.gnhs.org.uk/biodiversity/GBG_splist.pdf

The author of this contribution lives within $300 \mathrm{~m}$ of GBG and has visited the Gardens regularly from 1998 to 2020, averaging 2-3 visits per week. On each visit, bird numbers and species were noted. The compilation of these observations resulted in the most recent bird list shown in Table 1. Because this list shows the binomial names for each species, these have not been used in the main text. The 1998-2020 list has been tabulated with those of Grist \& McCallum (1998) to allow comparisons and to reveal trends and changes.

\section{RESULTS}

\section{Wildfowl}

Neither the greylag goose nor pink-footed goose were noted in previous lists. In recent years pink-footed geese have been seen most springs during March and April when migrating flocks pass north on their way to Arctic breeding grounds, often first apprehended by their farreaching honking calls. More rarely, returning flocks were noted in September and October. Greylag geese have also been recorded flying over but are more irregular. Much rarer, whooper swans have been seen passing just once: a flock of up to 80 on 29th March 2009; these too were migrating north. Another single was present in September 2017 on the River Kelvin (Forster, 2019).

The goosander has become a common breeding species along the River Kelvin in recent years and flocks of up to 12 birds have been recorded in winter. This increase follows its protection and consequent population growth across Scotland (Forrester et al., 2007). In the past, goosanders were controlled as they took fish in areas with angling interests.

\section{Heron, cormorant and gannet}

The rarest bird recorded at GBG, in a Scottish context, was an immature night-heron that remained from early November to 13th December 1926, being just the tenth national observation (Paterson, 1927). The night-heron was found "on a tree on the steep sloping bank of the Kelvin [and] resting on one leg with its head drawn back and its feathers bunched out and, with its crow-like head and moderately long and slightly decurved bill, it made a notable silhouette."

Cormorants are seen regularly flying overhead or foraging in the River Kelvin, sometimes in groups of up to three, at all times of the year. Just once, in September 2010, a juvenile gannet, a marine species, was watched following the course of the river.

\section{Birds of prey}

An addition to the list is the buzzard, with birds occasionally flying over the site. This reflects the increase in numbers and range of the species over the past 30 years throughout Scotland (Forrester et al., 2007). Pairs nest in east and north Glasgow with the birds seen at GBG likely deriving from these.

Another new bird of prey observed irregularly at GBG is the peregrine. These falcons have colonised urban areas, nesting in Glasgow on suitable tall buildings, hunting feral pigeons present throughout the city and are occasionally seen flying over.

\section{Shorebirds}

The oystercatcher and common sandpiper have both been recorded along the River Kelvin, and are new additions to the GBG bird list. These are summer passage migrants moving upstream to inland breeding areas. In the case of the oystercatcher they are usually heard while flying through, sometimes at night. 


\begin{tabular}{|c|c|c|c|c|c|c|}
\hline & & Trend & $\begin{array}{l}1894- \\
1901\end{array}$ & $\begin{array}{l}1966- \\
1985\end{array}$ & $\begin{array}{l}1994- \\
1997\end{array}$ & $\begin{array}{c}1998-2019 \\
\text { status }\end{array}$ \\
\hline Greylag goose & Anser anser & $\uparrow$ & - & - & - & $\mathrm{P}$ \\
\hline Pink-footed goose & Anser brachyrhynchus & $\uparrow$ & - & - & - & $\mathrm{P}$ \\
\hline Mute swan & Cygnus olor & & $\checkmark$ & $\checkmark$ & $\checkmark$ & RLB \\
\hline Whooper swan & Cygnus cygnus & & - & - & - & PV \\
\hline Mallard & Anas platyrhynchos & & - & $\checkmark$ & $\checkmark$ & $\mathrm{RB}$ \\
\hline Pochard & Aythya ferina & & - & $\checkmark$ & - & - \\
\hline Tufted duck & Aythya fuligula & & - & $\checkmark$ & - & $\mathrm{PV}$ \\
\hline Goosander & Mergus merganser & $\uparrow$ & - & $\checkmark$ & $\checkmark$ & $\mathrm{RB}$ \\
\hline Pheasant & Phasianus colchicus & & $\checkmark$ & - & - & - \\
\hline Little grebe & Tachybaptus ruficollis & & - & - & - & PV \\
\hline Night-heron* & Nycticorax nycticorax & & - & - & - & - \\
\hline Grey heron & Ardea cinerea & & - & - & $\checkmark$ & RLB \\
\hline Cormorant & Phalacrocorax carbo & & - & - & - & $\mathrm{P}$ \\
\hline Sparrowhawk & Accipiter nisus & & $\checkmark$ & $\checkmark$ & $\checkmark$ & $\mathrm{RB}$ \\
\hline Buzzard & Buteo buteo & $\uparrow$ & - & - & - & RLB \\
\hline Corncrake & Crex crex & & $\checkmark$ & - & - & - \\
\hline Moorhen & Gallinula chloropus & & $\checkmark$ & $\checkmark$ & $\checkmark$ & $\mathrm{RB}$ \\
\hline Coot & Fulica atra & & - & $\checkmark$ & - & - \\
\hline Oystercatcher & Haematopus ostralegus & & - & - & - & $\mathrm{P}$ \\
\hline Lapwing & Vanellus vanellus & & $\checkmark$ & - & - & - \\
\hline Woodcock & Scolopax rusticola & $\uparrow$ & - & - & - & $\mathrm{W}$ \\
\hline Snipe & Gallinago gallinago & & - & $\checkmark$ & - & - \\
\hline Common sandpiper & Actitis hypoleucos & & $\checkmark$ & - & - & $\mathrm{P}$ \\
\hline Common gull & Larus canus & & - & - & - & $\mathrm{P}$ \\
\hline Herring gull & Larus argentatus & $\uparrow$ & - & $\checkmark$ & $\checkmark$ & $\mathrm{RLB} / \mathrm{P}$ \\
\hline Lesser black-backed gull & Larus fuscus & $\uparrow$ & - & $\checkmark$ & $\checkmark$ & $\mathrm{RLB} / \mathrm{P}$ \\
\hline Sandwich tern & Thalasseus sandvicensis & & - & - & - & PV \\
\hline Common tern & Sterna hirundo & & - & - & - & PV \\
\hline Rock dove/feral pigeon & Columba livia & $\uparrow$ & - & $\checkmark$ & $\checkmark$ & $\mathrm{RB}$ \\
\hline Stock dove & Columba oenas & $\uparrow$ & - & - & - & $\mathrm{RB}$ \\
\hline Woodpigeon & Columba palumbus & $\uparrow$ & $\checkmark$ & $\checkmark$ & $\checkmark$ & $\mathrm{RB}$ \\
\hline Collared dove & Streptopelia decaocto & $\downarrow$ & - & $\checkmark$ & $\checkmark$ & RLB \\
\hline Cuckoo & Cuculus canorus & & $\checkmark$ & - & - & - \\
\hline Tawny owl & Strix aluco & & - & $\checkmark$ & $\checkmark$ & $\mathrm{RB}$ \\
\hline Swift & Apus apus & $\downarrow$ & $\checkmark$ & $\checkmark$ & $\checkmark$ & $\mathrm{SLB} / \mathrm{P}$ \\
\hline Kingfisher & Alcedo atthis & $\uparrow$ & - & $\checkmark$ & $\checkmark$ & $\mathrm{RB}$ \\
\hline Great spotted woodpecker & Dendrocopos major & $\uparrow$ & - & - & $\checkmark$ & $\mathrm{RB}$ \\
\hline Kestrel & Falco tinnunculus & & - & $\checkmark$ & $\checkmark$ & PV \\
\hline Peregrine & Falco peregrinus & $\uparrow$ & - & - & - & RLB \\
\hline Ring-necked parakeet & Psittacula krameri & $\uparrow$ & - & - & - & RLB \\
\hline Magpie & Pica pica & $\uparrow$ & $\checkmark$ & $\checkmark$ & $\checkmark$ & $\mathrm{RB}$ \\
\hline Jackdaw & Coloeus monedula & $\uparrow$ & $\checkmark$ & - & $\checkmark$ & RLB \\
\hline Rook & Corvus frugilegus & $\downarrow$ & $\checkmark$ & $\checkmark$ & - & - \\
\hline Carrion crow & Corvus corone & & $\checkmark$ & $\checkmark$ & $\checkmark$ & $\mathrm{RB}$ \\
\hline Raven & Corvus corax & 个 & - & - & - & RLB \\
\hline Waxwing & Bombycilla garrulus & & - & $\checkmark$ & - & WV \\
\hline Coal tit & Periparus ater & & & & & $\mathrm{RB}$ \\
\hline Blue tit & Cyanistes caeruleus & & $\checkmark$ & $\checkmark$ & $\checkmark$ & $\mathrm{RB}$ \\
\hline Great tit & Parus major & & $\checkmark$ & $\checkmark$ & $\checkmark$ & RB \\
\hline Skylark & Alauda arvensis & & - & - & - & PV \\
\hline Sand martin & Riparia riparia & $\uparrow$ & $\checkmark$ & - & - & LB \\
\hline Swallow & Hirundo rustica & & $\checkmark$ & - & - & $\mathrm{P}$ \\
\hline House martin & Delichon urbicum & & - & - & - & PV \\
\hline Long-tailed tit & Aegithalos caudatus & 个 & - & $\checkmark$ & $\checkmark$ & LB \\
\hline Willow warbler & Phylloscopus trochilus & $\uparrow$ & $\checkmark$ & - & - & $\mathrm{SLB} / \mathrm{P}$ \\
\hline
\end{tabular}




\section{Chiffchaff}

Wood warbler+

Blackcap

Garden warbler

Whitethroat

Firecrest+

Goldcrest

Wren

Nuthatch

Treecreeper

Starling

Blackbird

Fieldfare

Redwing

Song thrush

Mistle thrush

Spotted flycatcher

Robin

Redstart

Whinchat

Stonechat

Dipper

House sparrow

Dunnock

Yellow wagtail

Grey wagtail

Pied wagtail

Meadow pipit

Chaffinch

Brambling

Hawfinch+

Bullfinch

Greenfinch

Linnet

Lesser redpoll

Crossbill+

Goldfinch

Siskin

Corn bunting

Yellowhammer

Reed bunting
Phylloscopus collybita

Phylloscopus sibilatrix

Sylvia atricapilla

Sylvia borin

Sylvia communis

Regulus ignicapilla

Regulus regulus

Troglodytes troglodytes

Sitta europaea

Certhia familiaris

Sturnus vulgaris

Turdus merula

Turdus pilaris

Turdus iliacus

Turdus philomelos

Turdus viscivorus

Muscicapa striata

Erithacus rubecula

Phoenicurus phoenicurus

Saxicola rubetra

Saxicola rubicola

Cinclus cinclus

Passer domesticus

Prunella modularis

Motacilla flava

Motacilla cinerea

Motacilla alba

Anthus pratensis

Fringilla coelebs

Fringilla montifringilla

Coccothraustes coccothraustes

Pyrrhula pyrrhula

Chloris chloris

Linaria cannabina

Acanthis cabaret

Loxia curvirostra

Carduelis carduelis

Spinus spinus

Emberiza calandra

Emberiza citrinella

Emberiza schoeniclus

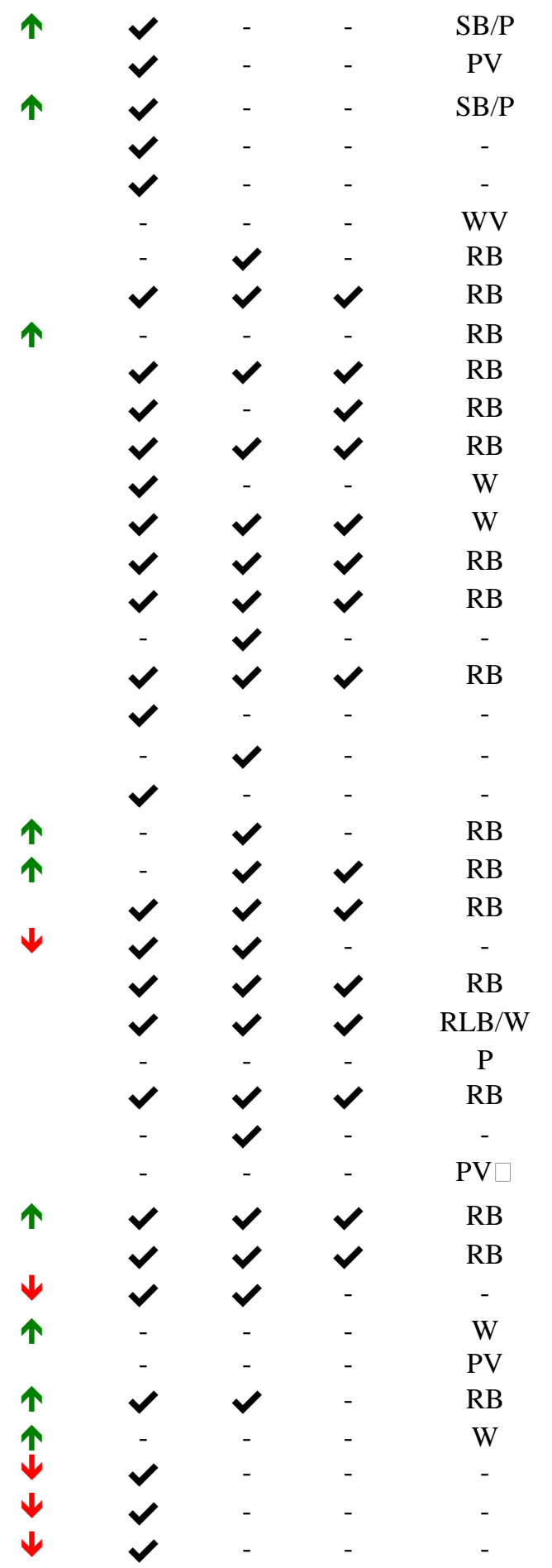

PV

$\mathrm{SB} / \mathrm{P}$

WV

$\mathrm{RB}$

$\mathrm{RB}$

$\mathrm{RB}$

$R B$

$\mathrm{RB}$

W

$\mathrm{W}$

$\mathrm{RB}$

$\mathrm{RB}$

$\mathrm{RB}$

$\mathrm{RB}$

$\mathrm{RB}$

$\mathrm{B} / \mathrm{W}$

$\mathrm{P}$

$\mathrm{V}$

$\mathrm{W}$

Table 1. Bird species seen in Glasgow Botanic Gardens, Scotland, from 1894 to 2020. The data for the first three columns (1894-1901, 1966-1985 and 1994-1997) are taken from Grist \& McCallum (1998). Trends over the period are indicated: $\uparrow=$ increasing; $\downarrow=$ decreasing; $\checkmark=$ present; $-=$ absent. For 1998-2020 the status codes are: RB $=$ resident breeder; SB $=$ summer breeder; RLB $=$ resident local breeder outside GBG; SLB = summer local breeder outside GBG; $\mathrm{W}=$ winter visitor; $\mathrm{P}=$ passage migrant; $\mathrm{V}=$ vagrant/rare; * seen just once in 1926 (Paterson, 1927); + seen near to GBG. The sequence of species and English names follows the 9th edition of the British List, as published by the British Ornithologists' Union (McInerny et al., 2018). 
The woodcock instead is a winter visitor to GBG from breeding areas elsewhere in Scotland or the continent. Birds wintering in Scotland are usually found in wooded and damp areas in the countryside but they can be present in cities during particularly cold weather when the ground freezes and prevents these ground-probing birds from feeding. The winter of 2010/11 was exceptionally cold during December with the River Kelvin icing over: a number of woodcocks were seen along the embankment. A corpse was found of a bird that had flown into a window of the author's house, which is preserved at National Museums Scotland, Edinburgh.

\section{Gulls and terns}

No gulls or terns breed in GBG, but both lesser blackbacked gulls and herring gulls nest widely throughout Glasgow on roof-tops, and are a common sight in the spring and summer breeding period. Black-headed gulls and common gulls are more irregular, occasionally seen passing through. Much rarer are the common tern and sandwich tern, both of which have been observed flying over once each in spring, in groups of two and three, respectively.

\section{Doves and pigeons}

An interesting addition to the breeding list of the Gardens is the stock dove (Fig. 1A), a species of arable and open countryside areas in Scotland (Forrester et al., 2007). In this context the discovery of a colony of up to nine nests in a stone wall along the River Kelvin, less than $1 \mathrm{~km}$ downstream of GBG, was noteworthy; this is the only known urban colony in Scotland and the U.K. (McInerny, 2018, 2020). Single pairs also breed in tall ivy-clad trees along the River Kelvin, with at least two nests within GBG.

Wood pigeons are conspicuous and common resident breeders. In contrast, the collared dove no longer breeds in the Gardens and is seen rarely, nesting in very small numbers nearby. This is a change in status for the species: Grist \& McCallum (1998) noted its natural colonisation of the U.K. since the 1950s and increase in numbers; the trend has now reversed at GBG and across Glasgow, for unknown reasons.

\section{Swift}

A species that has shown a marked decline in observations is the swift. During the 1990s it was a frequent summer breeding species in the West End of Glasgow, with birds often heard "screaming" overhead. Now it is largely absent from the area, with just a few passage birds moving to breeding areas elsewhere in Glasgow and Scotland.

\section{Parakeet}

An exotic addition to the list in recent times is the ringnecked parakeet. These introduced birds from the Indian subcontinent have been colonizing England for many years with very large numbers now present. Breeding was first confirmed in Scotland during 2016 at Victoria Park, Glasgow, just over $2 \mathrm{~km}$ to the west of GBG (McInerny, 2016, 2017), with increasing numbers subsequently elsewhere in Glasgow. At least two groups (four and six birds) have been seen flying over GBG revealed by their loud shrieking call. It seems likely that the species will nest in GBG in the future, as a preferred breeding habitat is suburban parks and gardens.

\section{Woodpecker and nuthatch}

Both the great spotted woodpecker and nuthatch now nest regularly in the Gardens. In the case of the nuthatch this reflects a striking range expansion for the species across Scotland in the past 20 years (Forrester et al., 2007). The only pair in GBG first arrived in December 2016 and has used the same bat box for nesting in four consecutive years, from 2017-2020 (Fig. 1B,C).
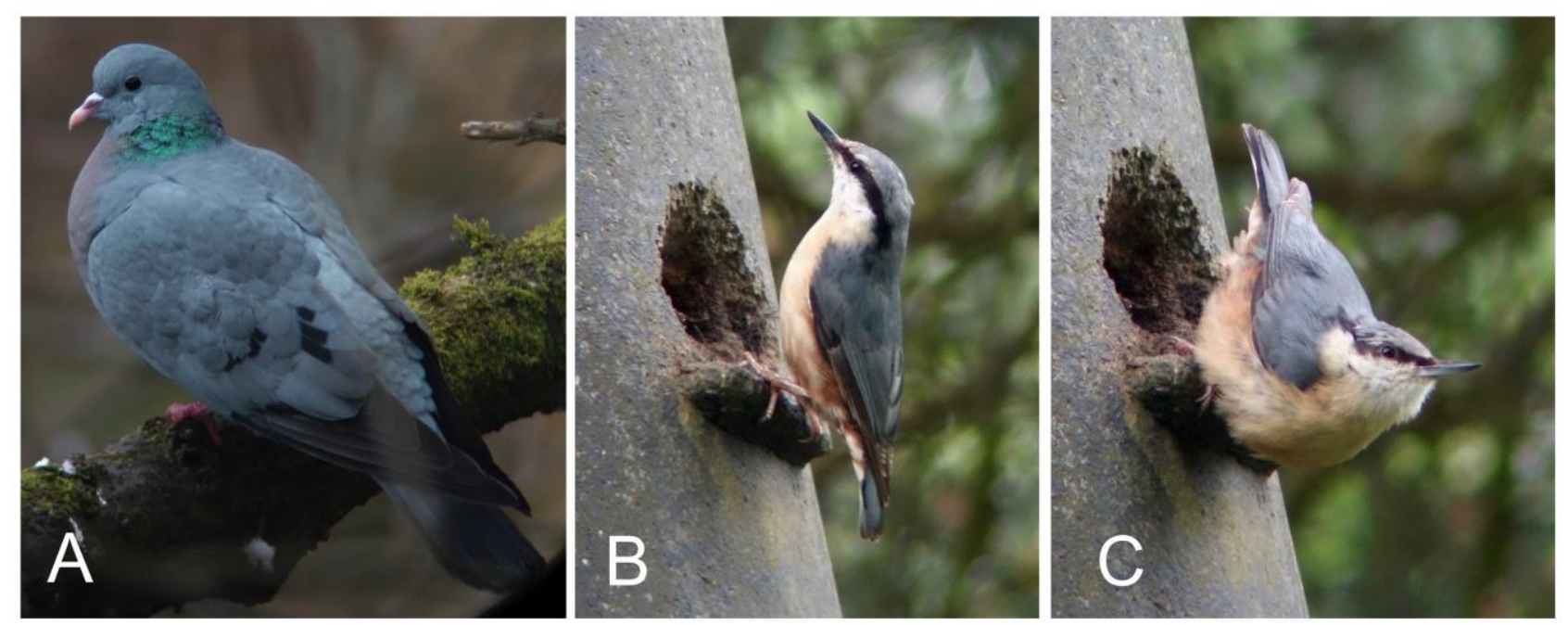

Fig. 1. Two bird species that have recently colonised Glasgow Botanic Gardens, Scotland, and which now breed every year. A. Stock dove (Columba oenas), 14th March 2018. These birds use tall ivy-clad trees along the River Kelvin for nest sites, where this individual was photographed. Nuthatch (Sitta europaea), male (B) and female (C), 22nd May 2020. This pair raised young in a bat box in the Gardens, which they had used for nesting the previous two years. (Photos: C.J. McInerny) 


\section{Corvids and waxwing}

Raven and jackdaw numbers have both increased in the past ten years. The former now breed nearby with pairs at the University of Glasgow and the Anniesland gasometers, with birds regularly flying over GBG revealed by their deep croaking calls. Jackdaws have bred in the city for much longer, but have recently become more common and widespread, and so are often heard and seen.

Waxwings visit Glasgow most winters in small numbers, with the last flock in GBG of up to 110 birds, from 23rd to 28th November 2016.

\section{Passerines}

A number of passerine species have been observed more over the past ten years: the sand martin, dipper, house sparrow, goldfinch and bullfinch.

Sand martins are increasingly seen in GBG, usually flying up and down the River Kelvin. This reflects both a recovery in the species' fortunes in Scotland (Forrester et al., 2007), and that they breed locally along the river. Interestingly, downstream in Partick, the nest sites are not the usual sand banks but instead holes in concrete walls overlooking the river; multiple pairs can use the same entrance hole.

During the 1990s the dipper was only occasionally observed along the River Kelvin during the winter but, more recently, breeding pairs can be found along the entire course of the river that passes through the West End of Glasgow; their distinctive "kkkrrrrrr" call is a familiar sound. This increase is possibly linked to improvements in water quality; grey wagtails and kingfishers both also nest along the river.

House sparrow numbers have started to recover in the past five years from a historic low (Dott \& Brown, 2000; Summers-Smith, 2003), with groups now again present where suitable vegetation such as thick hedges or ivyclad walls are found. Goldfinches are common and widespread, with bullfinches frequently heard and seen.

Summer migrant warblers have also increased in numbers in recent years. More blackcaps and chiffchaffs are recorded in the Gardens, not only as breeding birds, but also on passage in spring and late summer/autumn. Willows warblers have shown the same increase in passage numbers but breed elsewhere, some nearby. Wood warblers have been observed just twice, both in April, near to GBG on passage presumably to breeding areas further north in Scotland.

New to the list, meadow pipits were recorded each autumn as passage migrants, with the skylark more infrequent: for example, two of the latter were heard and seen flying over on 1st November 2008. Both siskins and lesser redpolls were noted as regular winter visitors.

Three very rare observations during the period were of the firecrest, crossbill and hawfinch, with each seen just once in the vicinity of GBG. The male firecrest was present from 11th to 31st December 2017, the crossbills a group of two or three birds flying past on 14th April 2020 giving their "chip chip" call, and the hawfinch on 21st April 2005 (McInerny, 2007).

\section{DISCUSSION}

GBG hosts an interesting range of species of birds, some of which have shown striking fluctuations over the years. It will be fascinating to see what further changes occur in the future and which new species will be next added to the GBG bird list. My predictions include the pied flycatcher (Ficedula hypoleuca), sedge warbler (Acrocephalus schoenobaenus) and tree pipit (Anthus trivialis), all of which breed in Scotland as summer visitors from Africa, and likely pass through the area on migration; and the Jay (Garrulus glandarius), a resident breeder which is expanding its range and had been noted recently in north Glasgow.

\section{REFERENCES}

Dott, H.E.M. \& Brown, A.W. (2000). A major decline in house sparrows in central Edinburgh. Scottish Birds 21, 61-68.

Downie, J.R. \& Forster, S.J. (2019). On the wildside 2: the natural history of the Glasgow Botanic Gardens revisited. The Glasgow Naturalist 27(1), 49. https://doi.org/10.37208/tgn27108

Forrester, R.W., Andrews, I.J., McInerny, C.J., Murray, R.D., McGowan, R.Y., Zonfrillo, B. et al. (Editors). (2007). The Birds of Scotland. The Scottish Ornithologists' Club, Aberlady.

Forster, S.J. (2019). A “wild day out!": finding wildlife in the Glasgow Botanic Gardens. The Glasgow Naturalist 27(1), 50-52. https://doi.org/10.37208/tgn27109

Grist, N.R. \& McCallum, I.C. (1998). Birds for all seasons. The Glasgow Naturalist 23(3), 52-54.

McInerny, C.J. (2007). Hawfinch in Clyde. Clyde Birds $17,120-125$.

McInerny, C.J. (2016). Ring-necked parakeets potentially nesting in Scotland for the first time. Scottish Birds 36, 211-212.

McInerny, C.J. (2017). Ring-necked parakeets successfully breed in Scotland for the first time. Scottish Birds 37, 316.

McInerny, C.J. (2018). Wall-nesting urban stock doves in Glasgow. Scottish Birds 38, 141-142.

McInerny, C.J. (2020). Annual occupancy of an urban stock dove colony in Glasgow. Scottish Birds 40, 128-130.

McInerny, C.J., Musgrove A.J., Stoddart A., Harrop A.H.J., Dudley S.P. \& British Ornithologists' Union Records Committee (BOURC). (2018). The British List: a Checklist of Birds of Britain (9th edition). Ibis 160, 190-240. https://doi.org/10.1111/ibi.12536

Paterson, J. (1927). Night-heron in Glasgow. Scottish Naturalist 1927, 14. https://www.biodiversitylibrary.org/item/204149\#p age/26/mode/1up

Summers-Smith, J.D. (2003). The decline of the house sparrow: a review. British Birds 96, 439-446. 